\title{
Hylodesmus singaporensis gen. et sp. nov., a new autosporic subaerial green alga (Scenedesmaceae, Chlorophyta) from Singapore
}

Correspondence
Marek Eliáš
melias@natur.cuni.cz

\section{INTRODUCTION}

Coccoid green algae that reproduce solely by means of autosporulation represent one of the most difficult groups in terms of achieving natural taxonomy. Traditionally, these algae were classified as a subgroup of the green algal order Chlorococcales (Komárek \& Fott, 1983), although it has been long recognized that they do not form a

Abbreviations: LBA, long branch-attraction; ML, maximum-likelihood; SEM, scanning electron microscopy; TEM, transmission electron microscopy.

The GenBank/EMBL/DDBJ accession numbers for the 18S rRNA gene-ITS2-5.8S rRNA gene-ITS2 region of Hylodesmus singaporensis strains CAUP H 8001 and E4-g are FJ436342 and FJ715936, respectively.

The predicted secondary structure of the ITS2 region of Hylodesmus singaporensis strain CAUP H 8001 and ML phylogeny of the ITS2 region of Scenedesmaceae are available with the online version of this paper. phylogenetically coherent assemblage. The revolutionary concept of green algal classification pioneered by Mattox \& Steward (1984) and based on the ultrastructural features of the flagellar apparatus cannot be applied to taxa lacking flagellated stages. For this reason, gaining insight into the actual phylogenetic relationships of autosporic chlorophytes only became possible with the advent of molecular approaches (e.g. Huss \& Sogin, 1990). Molecular phylogenetic studies, based primarily on $18 \mathrm{~S}$ rRNA gene sequences, revealed that autosporic green algae form an array of unrelated lineages, the majority of which belong to the class Trebouxiophyceae or to the order Sphaeropleales within the class Chlorophyceae (e.g. Hanagata, 1998; Huss et al., 1999; Hepperle et al., 2000; Krienitz et al., 2003; Wolf et al., 2003a, b; Senousy et al., 2004; Fawley et al., 2005).

One of the most prominent lineages of the autosporic coccoid green algae is one that roughly corresponds to the traditional family Scenedesmaceae. The circumscription of 
this family, since it was established by Oltmanns (1904), has varied greatly depending on the author (Komárek \& Fott, 1983; Ettl \& Gärtner, 1995; Hegewald \& Hanagata, 2000). Here, we understand the family Scenedesmaceae to be a monophyletic lineage within the order Sphaeropleales consisting of autosporic green algae of the genus Scenedesmus and its relatives. Following the most recent molecular phylogenetic studies and taxonomic revisions (Hegewald \& Hanagata, 2000; Krienitz et al., 2003), genera in this family now include: Scenedesmus, Coelastrella, Neodesmus, Desmodesmus, Pseudodidymocystis and Hariotina. Species attributed to the genera Enallax, Coelastropsis, Pectodictyon and Coelastrum have also been shown to cluster within the Scenedesmaceae lineage (Hegewald \& Hanagata, 2000; Krienitz et al., 2003), but their taxonomic status is uncertain at present (mostly due to lack of molecular data on the type species of the genera). In addition, Tsarenko raised the subgenus Acutodesmus of the genus Scenedesmus to the level of a separate genus (Tsarenko \& Petlevanny, 2001), although this treatment has become controversial in light of more recent molecular evidence (Hegewald \& Wolf, 2003). Nevertheless, further genera will doubtless be added to the Scenedesmaceae in the future by reclassification of known taxa, but also by the inclusion of novel organisms, not previously described.

An exceptionally rich source of novel phylogenetic diversity of coccoid green algae has been found in the subaerial habitats in tropical ecosystems (Rindi et al., 2006; Neustupa et al., 2007; Eliáš et al., 2008; Zhang et al., 2008; Neustupa et al., 2009). In the course of our investigation into green algal cultures sampled from decaying wood in a natural forest in Singapore, we found a strain of a coccoid green alga occupying an interesting position in the $18 \mathrm{~S}$ rRNA genebased phylogenetic tree of the Scenedesmaceae. In order to learn more about this organism, we conducted a detailed morphological, ultrastructural and molecular phylogenetic study, and, based on our results, we describe a new genus and species, Hylodesmus singaporensis gen. et sp. nov. (Scenedesmaceae, Chlorophyta).

\section{METHODS}

Isolation and cultivation. The type strain of $H$. singaporensis (CAUP $\mathrm{H}$ 8001), along with a morphologically indistinguishable strain (E4-g) cloned out independently from a different colony, were isolated from a subaerial algal growth taken from a $10 \times 10 \mathrm{~cm}$ site on decaying bare wood in a tropical forest in the Central Catchment Nature Reserve, Singapore $\left(1^{\circ} 21^{\prime} 12.56^{\prime \prime} \mathrm{N}\right.$ and $103^{\circ} 48^{\prime} 43.09^{\prime \prime} \mathrm{E}$; altitude $60 \mathrm{~m}$ above sea level). For purposes of this study, the algae were cultivated on agar-solidified or liquid BBM medium (Bischoff \& Bold, 1963), as well as in liquid CAUP OGM medium (http://botany.natur.cuni.cz/ algo/caup.html). The cultures were maintained at $23{ }^{\circ} \mathrm{C}$ with illumination of $40 \mu \mathrm{mol} \mathrm{m}{ }^{-2} \mathrm{~s}^{-1}$ provided by $18 \mathrm{~W}$ cool fluorescent tubes (Philips TLD 18W/33).

Microscopy. General vegetative and reproductive morphology was examined under an Olympus BX51 light microscope. Microphotographs were taken with Olympus Z5060 equipment using differential contrast. To visualize details of the cell wall, cells were stained with calcofluor white solution (Fritz \& Triemer, 1985) and examined under an Olympus BX-41 microscope equipped with an Olympus U-RFL-T-200 epifluorescence illumination lamp. The UV filter was set at an excitation wavelength of $330-380 \mathrm{~nm}$ and an emission wavelength of $420 \mathrm{~nm}$. For investigation of chloroplast morphology, cells were observed with a Leica TCS SP2 laser scanning confocal microscope. The microscope was equipped with an Ar-Kr laser using a $488 \mathrm{~nm}$ excitation line and an AOBS filter-free system collecting emitted light between 498 and $700 \mathrm{~nm}$. A Leica $63 \times / 1.4$ N.A. oil immersion or $63 \times / 1.2$ water immersion objective fitted on a Leica DM IRE2 inverted microscope was used. A series of optical sections of chloroplasts was captured and used for $3 \mathrm{D}$ reconstruction. The autofluorescence of the chlorophyll was exploited for visualization of chloroplast structure. For the final processing of confocal images, various image analysis tools were applied using ImageJ $1.34 \mathrm{p}$ (Abramoff et al., 2004) and Adobe Photoshop CS3 Extended. For transmission electron microscopy (TEM), samples were fixed in $2 \%$ glutaraldehyde, post-fixed in $1 \%$ osmium tetroxide in $0.05 \mathrm{M}$ phosphate buffer and $1 \%$ uranyl acetate in methanol. After dehydration in ethanol, the cells were embedded in Spurr's medium via isobutanol. Ultrathin sections, cut with a diamond knife on a Reichert-Jung Ultracut, were post-stained with lead citrate and examined with a JEOL 1011 TEM. Obtaining empty cell walls was achieved by mechanically breaking the cells by vortexing in a plastic tube with glass beads ( $0.5 \mathrm{~mm}$ diam.; Sigma). Cell walls were then collected by successive centrifugation. Washed walls were dried onto Formvar-coated grids and examined with the JEOL 1011 TEM. Samples for scanning electron microscopy (SEM) were processed using a procedure similar to that described by Poulíčková et al. (2007). In brief, fixed samples ( $2 \%$ glutaraldehyde, $0.1 \mathrm{M}$ phosphate buffer) were rigorously washed with $0.1 \mathrm{M}$ cacodylate buffer and allowed to sediment onto poly-L-lysine-treated Nucleopore filters for 3 days at $4{ }^{\circ} \mathrm{C}$. Filters with attached cells were dehydrated through a series of ethanol baths. Finally, the filters were coated with gold in a sputter-coater (Polaron). The specimens were examined in a Philips CM12/STEM electron microscope in SEM mode at $80 \mathrm{kV}$, spot size $10 \mathrm{~nm}$.

Gene sequencing. For isolation of genomic DNA, cells were scraped from an agar plate with a clean spatula, transferred into an Eppendorf tube, resuspended in distilled water and harvested by centrifugation. Total DNA was extracted using the Invisorb Spin Plant Mini kit (Invitek). The sequence of the 18S rRNA gene-ITS1-5.8S rRNA geneITS2 region was obtained by PCR amplification, followed by the sequencing of two overlapping segments. The segment representing the $18 \mathrm{~S}$ rRNA gene was amplified by using the universal forward (F) and reverse (R) primers according to Katana et al. (2001); the second segment comprising part of the 18S rRNA gene and the ITS1-5.8S rRNA gene-ITS2 region was amplified using the 1500af primer (Helms et al., 2001) and a newly designed primer (5'-GTTCAGCGGGTAGCCTTGC-3') matching the $5^{\prime}$ end of the $28 \mathrm{~S}$ rRNA gene (amplification with the standard ITS4 primer failed). The PCR products were resolved by electrophoresis on a vertical $1 \%$ agarose gel, bands of the expected size were excised and the DNA was purified using the QIAquick Gel Extraction kit (Qiagen). The first segment was sequenced from both ends using the amplification primers, internal sequencing primers from Katana et al. (2001) and a newly designed reverse primer (5'-GCATCGTTTATGGTTGAGAC-3') that was required because of the presence of a long intron. The second segment was sequenced with the amplification primers and with the ITS1 primer (White et al., 1990). Sequencing reactions were performed using the BigDye Terminator v3.1 Cycle Sequencing kit (Applied Biosystems) and analysed with the 3130 Genetic Analyzer (Applied Biosystems). Sequencing reads were assembled with the CAP3 assembler server (http://pbil.univ-lyon1.fr/cap3.php) and manually edited by visual inspection of sequencing chromatograms. We did not observe any differences in the sequences of the 
overlapping regions of the two segments. The newly obtained sequence of the 18S rRNA gene-ITS1-5.8S rRNA gene-ITS2 region of $H$. singaporensis (excluding the regions representing the amplification primers) was deposited in GenBank with the accession number FJ436342 (strain CAUP H 8001) and FJ715936 (strain E4-g).

Phylogenetic analyses. A multiple alignment of the newly determined 18S rRNA gene sequence and other sequences selected from the GenBank/EMBL/DDBJ databases was built using CLUSTAL_X (Thompson et al., 1997). This was then manually curated in GeneDoc (www.nrbsc.org/gfx/genedoc/) taking into account the secondary structure model for the Chlamydomonas reinhardtii $18 \mathrm{~S}$ rRNA molecule available from the European rRNA Database (www.psb. ugent.be/rRNA/secmodel/Crei_SSU.html; Wuyts et al., 2000). A widely sampled maximum-likelihood (ML) phylogenetic analysis demonstrated that $H$. singaporensis is firmly nested within the Scenedesmaceae clade (tree not shown). We therefore prepared a dataset combining the new sequence with all previously available, sufficiently complete scenedesmacean $18 \mathrm{~S}$ rRNA gene sequences, which were selected from a comprehensive dataset of chlorophycean $18 \mathrm{~S}$ rRNA gene sequences on the basis of a distance tree (BIONJ; Gascuel, 1997). Several sequences from representatives of the Hydrodictyaceae, Neochloridaceae and Selenastraceae (all Sphaeropleales) were included, and two representatives of the Volvocales were also included to provide a suitable outgroup (based on the preliminary BIONJ tree). The final alignment of the 18S rRNA gene sequences used for phylogenetic analyses presented herein comprised 74 sequences and 1747 unambiguously aligned positions. A multiple alignment of ITS2 sequences was constructed by eye, taking into account previously published secondary structure models of the scenedesmacean ITS2 region (van Hannen et al., 2002; Hegewald \& Wolf, 2003; Lewis \& Flechtner, 2004; Hegewald et al., 2005; Jeon \& Hegewald, 2006). To guide the alignment, we also built a model of the ITS2 secondary structure of $H$. singaporensis (Fig. S1 in IJSEM online) using RNAstructure 4.5 (Mathews et al., 2004) with the default parameter setting. For phylogenetic analyses we discarded ambiguously aligned regions, yielding a final alignment of 191 positions. Based on a preliminary analysis, we selected 60 representative sequences to infer the tree presented in Fig. S2 (in IJSEM online). All alignments used in this study are available upon request. An ML analysis of the 18S rRNA gene data was carried out with the RAxML-VI-HPC 2.2.3 program (Stamatakis, 2006) employing the GTRGAMMA substitution model (the most general model implemented by the program). ML bootstrap support was calculated from 100 bootstrap replicates. Evaluation of tree topology was also performed by calculating 1000 bootstrap BIONJ trees from distance matrices inferred by the DNADIST program (PHYLIP 3.6 package; Felsenstein 2004) employing the F84 model of nucleotide evolution, a transition/transversion ratio of 2.0, one rate category and no gamma correction. An ML analysis of the ITS2 data was done using the RAxML 7.0.4 program accessed through the CIPRES (Cyberinfrastructure for Phylogenetic Research) Portal (www.phylo. org/sub_sections/portal/). We employed a tree inference strategy that was recently demonstrated to be particularly effective in finding a tree with the highest likelihood, i.e. combining a new rapid bootstrap algorithm to infer 100 bootstrap trees with subsequent thorough ML inference on the original dataset utilizing the bootstrap trees for further optimization with the GTRGAMMAI model (Stamatakis et al., 2008). Bayesian inference was performed using MRBAYES 3.1 (Huelsenbeck \& Ronquist 2001). Two parallel MCMC runs were carried out for 2 million generations each with one cold and three heated chains employing the GTRGAMMAI evolutionary model (with parameters estimated from the data). Trees were sampled every 100 generations. The initial 6000 (18S rRNA gene dataset) or 500 (ITS2 dataset) trees of each run were discarded as 'burn-in' and posterior probabilities of tree bipartitions were calculated on the basis of the consensus of the remaining trees. An ITS2 ML tree with a constrained tree topology was inferred with RAxML 7.0.4 employing the procedure used for the unconstrained ML tree. Per-site loglikelihoods for the alternative trees were computed with RAxML 7.0.3 (-f g option) and fed into CONSEL (Shimodaira \& Hasegawa, 2001) to calculate $P$ values of the approximately unbiased (AU) test (Shimodaira, 2002).

\section{RESULTS}

\section{Hylodesmus Eliáš, Němcová, Škaloud \& Neustupa, gen. nov.}

Diagnosis latina. Cellulae vegetativae singulares, sphericae vel ellipsoideae, uninucleatae. Paries cellularis in microscopio optico glabra; in microscopio electronico, superficies cum costis paucis persubtilibus, cum strato interno polysaccharato et cum externo trilaminari. Chloroplastus parietalis cum 1 pirenoide. Matrix pyrenoidis sine penetrantibus lamellis thylacoidum. Propagatio asexualis per autosporas. Substantiae carotenoides secundae absentes. A generibus ceteris familiae ordine nucleotidorum in $18 \mathrm{~S}$ rRNA and ITS2 differt.

Description. Vegetative cells solitary, spherical or ellipsoidal, uninucleate. The cell wall in an optical microscope appears smooth; in an electron microscope, the cell wall composed of an internal polysaccharide layer and an external trilaminar layer, the surface with a few delicate ribs. The chloroplast parietal with a single pyrenoid. The pyrenoid matrix is not penetrated by thylakoid lamellae. Asexual reproduction via autospores. Secondary carotenoids not produced. The sequences of the $18 \mathrm{~S}$ rRNA gene and the ITS2 region differ from other genera of the family.

Type species. Hylodesmus singaporensis Eliáš, Němcová, Škaloud \& Neustupa

Etymology. The genus name Hylodesmus (masc. n.) is derived from the Greek terms hyle (wood) and desmos (bond), analogous to several other generic names of the Scenedesmaceae family, and referring to the habitat where the first representative was collected.

\section{Hylodesmus singaporensis Eliáš, Němcová, Škaloud \& Neustupa, sp. nov.}

Diagnosis latina. Cellulae vegetativae singulares, uninucleatae. In agaro cellulae sphaericae, (4.2)5.5-9.5(-11.0) $\mu \mathrm{m}$ diametro. In medio liquido cellulae sphaericae vel ellipsoideae (5.0-)5.5-10.8(-12.4) $\mu \mathrm{m}$ longae et (3.0-)4.0-7.5(-9.0) $\mu \mathrm{m}$ latae. Chloroplastus parietalis cum 1 pyrenoide, interdum perforatus praedita. Propagatio asexualis per 2-16 autosporas. Autosporae interdum sphaericae, 3-5 $\mu \mathrm{m}$ in diametro.

Description. Vegetative cells solitary, uninucleate. On agar media cells spherical, (4.2)5.5-9.5(-11.0) $\mu \mathrm{m}$ in diameter. In liquid media cells spherical or ellipsoidal, 
(5.0-)5.5-10.8(-12.4) $\mu \mathrm{m}$ in length and (3.0-)4.0 $7.5(-9.0) \mu \mathrm{m}$ in width. Parietal chloroplast with one pyrenoid, usually perforated. Asexual reproduction via 216 autospores. Autospores usually spherical, $3-5 \mu \mathrm{m}$ in diameter.

Holotype. Strain CAUP C-H8001 is permanently cryopreserved in the Culture Collection of Algae of Charles University in Prague, Czech Republic (CAUP, http://botany.natur.cuni.cz/algo/caup.html). CAUP C-H8001 is also maintained in an active culture as CAUP H 8001, from which the holotype was derived.

Type locality. Subaerial algal growth on decaying bare wood in a tropical forest in the Central Catchment Nature Reserve, Singapore $\left(1^{\circ} 21^{\prime} 12.56^{\prime \prime} \mathrm{N}\right.$ and $103^{\circ} 48^{\prime} 43.09^{\prime \prime} \mathrm{E}$; altitude $60 \mathrm{~m}$ above sea level).

Etymology. The name singaporensis refers to the country where the type material was collected.

\section{Morphology and ultrastructure}

The morphological appearance of $H$. singaporensis varied depending on culture conditions. When grown on solid medium, it formed cells that were predominantly globular, with dimensions (4.2-)5.5-9.5(-11.0) $\mu \mathrm{m}$ in diameter (Fig. 1a-c; Fig. 2a). In liquid media (OGM or BBM), a proportion of cells assumed an irregularly oval shape of (5.0-)5.5-10.8(-12.4) $\mu \mathrm{m}$ in length and (3.0-)4.0 $7.5(-9.0) \mu \mathrm{m}$ in width (Fig. $1 \mathrm{~d}-\mathrm{g}$ ). Autosporulation in oval or spherical sporangia was the only means of reproduction observed (Fig. 1h-i; Fig. 2b). The autospores were typically globular, 3-5 $\mu \mathrm{m}$ in diameter (Fig. $1 \mathrm{j}, \mathrm{k}$ ). The number of daughter cells per autosporangium generally differed in cultures grown on solid vs liquid media (2-4 or 4-16, respectively). Each cell possessed a single parietal chloroplast typically extended over most of the inner cellular surface (Fig. 11). The chloroplast was perforated by apertures of varying shape (Fig. 1m, n). Before autosporogenesis, the chloroplast divided into several polygonal plates or strips (Fig. 1n). The chloroplast contained a conspicuous pyrenoid with a starch envelope composed, in most cases, of two halves (Fig. 1b, e; Fig. 2e, f). No thylakoids transecting the pyrenoid matrix were observed. The region between the plasma membrane and the chloroplast was occupied by a number of vacuoles of varying size (Fig. 2e, f, i). A different type of spherical vacuole, containing electron-dense granular material, was often seen in the region between the parietal chloroplast and the nucleus (Fig. 1b, o; Fig. 2e, f). The cell wall was composed of two main layers: a thick inner layer and a thin outer trilaminar layer. The cell wall surface was ornamented by two to five delicate, predominantly meridional ribs (Fig. 2a, c, d) formed by a thickening of the inner cell wall layer (Fig. 2 g-i). The loose and irregular granulation on the cell surface visible by SEM (Fig. 2a) was probably precipitation of inorganic material. Remnants of a shed parental cell wall were detected in the medium (Fig. 2f). Autospores often retained a part of the parental cell wall on their surface (Fig. 2h, j, k). Old cultures did not produce secondary carotenoids.

From the sample of algal growth that provided the CAUP H 8001 strain of $H$. singaporensis, we also isolated another independent strain (E4-g), which under light microscopy appeared identical to strain CAUP H 8001 (data not shown), but differed at the molecular level (see below).

\section{Molecular phylogenetic analysis}

The determined sequence of the 18S rRNA gene-ITS1-5.8S rRNA gene-ITS2 region of $H$. singaporensis CAUP H 8001 comprises $3175 \mathrm{bp}$, including two group I introns (341 bp and $428 \mathrm{bp}$ ) in the $18 \mathrm{~S}$ rRNA gene. BLASTN searches and ML phylogenetic analysis of a broader set of chlorophyte $18 \mathrm{~S}$ rRNA gene sequences placed $H$. singaporensis firmly into the family Scenedesmaceae within the chlorophycean order Sphaeropleales (data not shown). In order to determine the position of $H$. singaporensis more precisely, we conducted a more focused analysis using all available sufficiently complete $18 \mathrm{~S}$ rRNA gene sequences of representatives of the Scenedesmaceae plus several suitable outgroup species (Fig. 3). In this analysis, $H$. singaporensis branched with $100 \% / 100 \% \mathrm{ML} / \mathrm{BIONJ}$ bootstrap support and 1.00 Bayesian posterior probability as a sister lineage of a strongly supported monophyletic (100\%/ $100 \% / 1.00)$ Desmodesmus clade. The Hylodesmus + Desmodesmus clade was in turn sister with varying support (64\%/85\%/1.00) to Pseudodidymocystis planctonica. The Neodesmus clade branched off immediately basal to the Hylodesmus + Desmodesmus + Pseudodidymocystis clade with statistical support from Bayesian inference only. The position of this larger clade, which corresponds to the subfamily Desmodesmoideae (Hegewald \& Hanagata, 2000) within the Scenedesmaceae was unresolved in our analysis. In addition, our analysis strongly suggested a close relationship of Dimorphococcus lunatus and two Scenedesmus arcuatus varieties, and of Hariotina reticulata and Pectodictyon pyramidale. It further supported the existence of a clade corresponding to the genus Coelastrella, and of two distinct clades of traditional Scenedesmus species here referred to as Scenedesmus (sensu stricto) and Acutodesmus (sensu stricto). Support for the deepest nodes within the Scenedesmaceae was lacking, but the family as a whole was separated from other lineages of the order Sphaeropleales (here represented by families Hydrodictyaceae, Neochloridaceae and Selenastraceae), by a relatively long branch with the highest statistical support.

Because the ITS2 region is an important alternative marker for investigating the phylogenetic relationship within the Scenedesmaceae (An et al., 1999; van Hannen et al., 2002; Hegewald \& Wolf, 2003), we analysed the phylogenetic position of $H$. singaporensis with respect to previously determined ITS2 sequences from the Scenedesmaceae. In BLASTN searches against the non-redundant nucleotide 


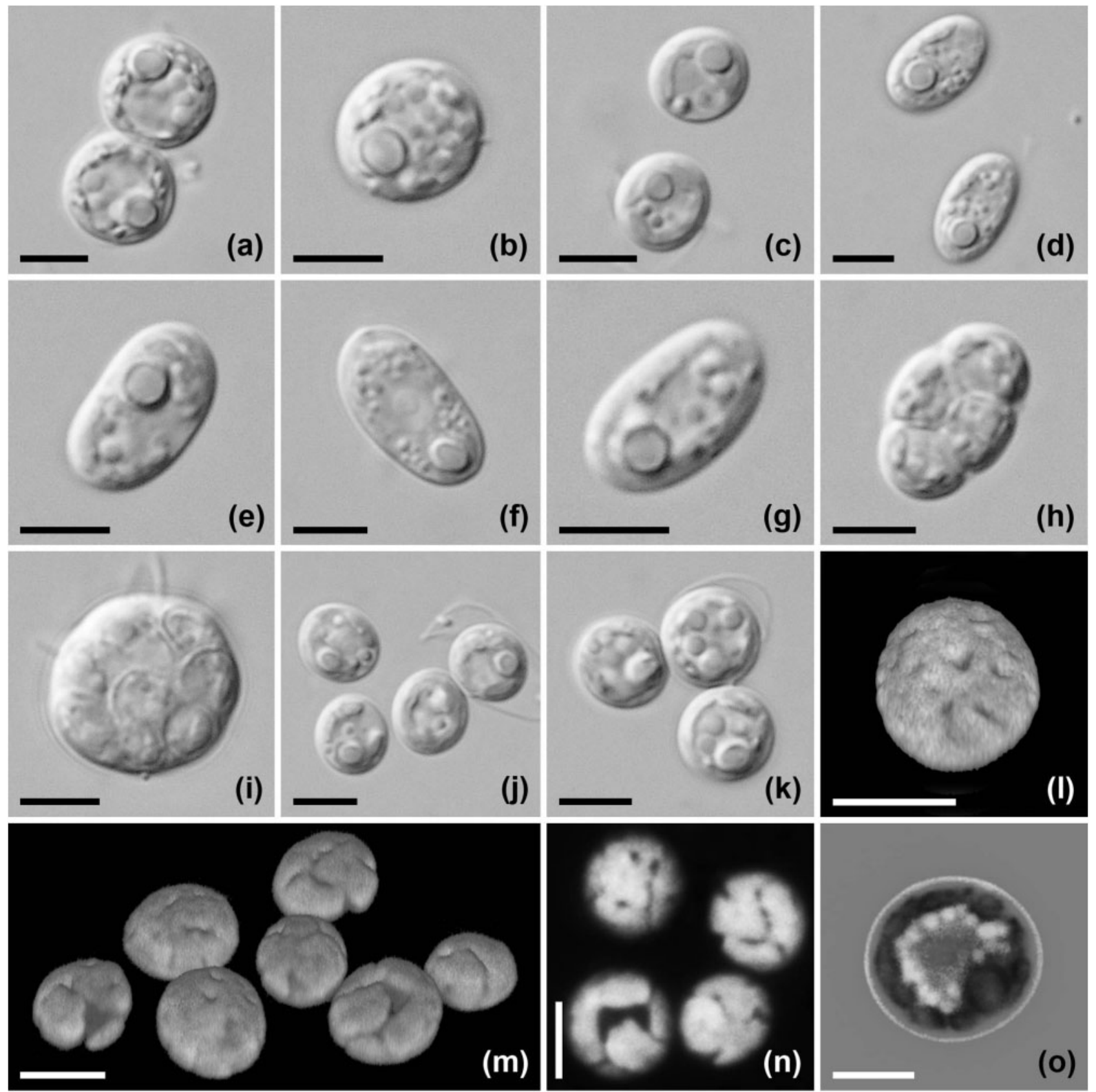

Fig. 1. Morphology of Hylodesmus singaporensis gen. et sp. nov. CAUP H 8001. (a-c) Globular vegetative cells growing on solid medium. $(\mathrm{d}-\mathrm{g})$ Oval vegetative cells in liquid medium; note the eccentrically positioned prominent pyrenoid. ( $h$, i) Autosporangia of various shapes. ( $\mathrm{j}, \mathrm{k}$ ) Released globular autospores. (I, m) 3D confocal reconstructions of the chloroplasts in mature vegetative cells; note several chloroplast perforations of various shapes. (n) Maximum projection of confocal sections through the chloroplasts; note the splitting of the compact parietal chloroplast into several polygonal plates before autosporogenesis (clearly visible in the bottom left cell). (o) A computer-processed epifluorescence image of a mature vegetative cell; note the parietal chloroplast (dark) spread along the inner cell surface and numerous spherical vacuoles (light) situated beneath the chloroplast layer. Bars, $5 \mu \mathrm{m}$.

database at NCBI (http://blast.ncbi.nlm.nih.gov/Blast.cgi), the $H$. singaporensis ITS2 sequence, used as a query, returned ITS2 sequences from scenedesmacean species, and especially from Desmodesmus spp., as being the most similar, but no sequence shared more than $75 \%$ identical positions. The ML tree calculated from ITS2 sequences of selected scenedesmacean representatives was not particularly well-resolved, owing to rather few (191) reliably 


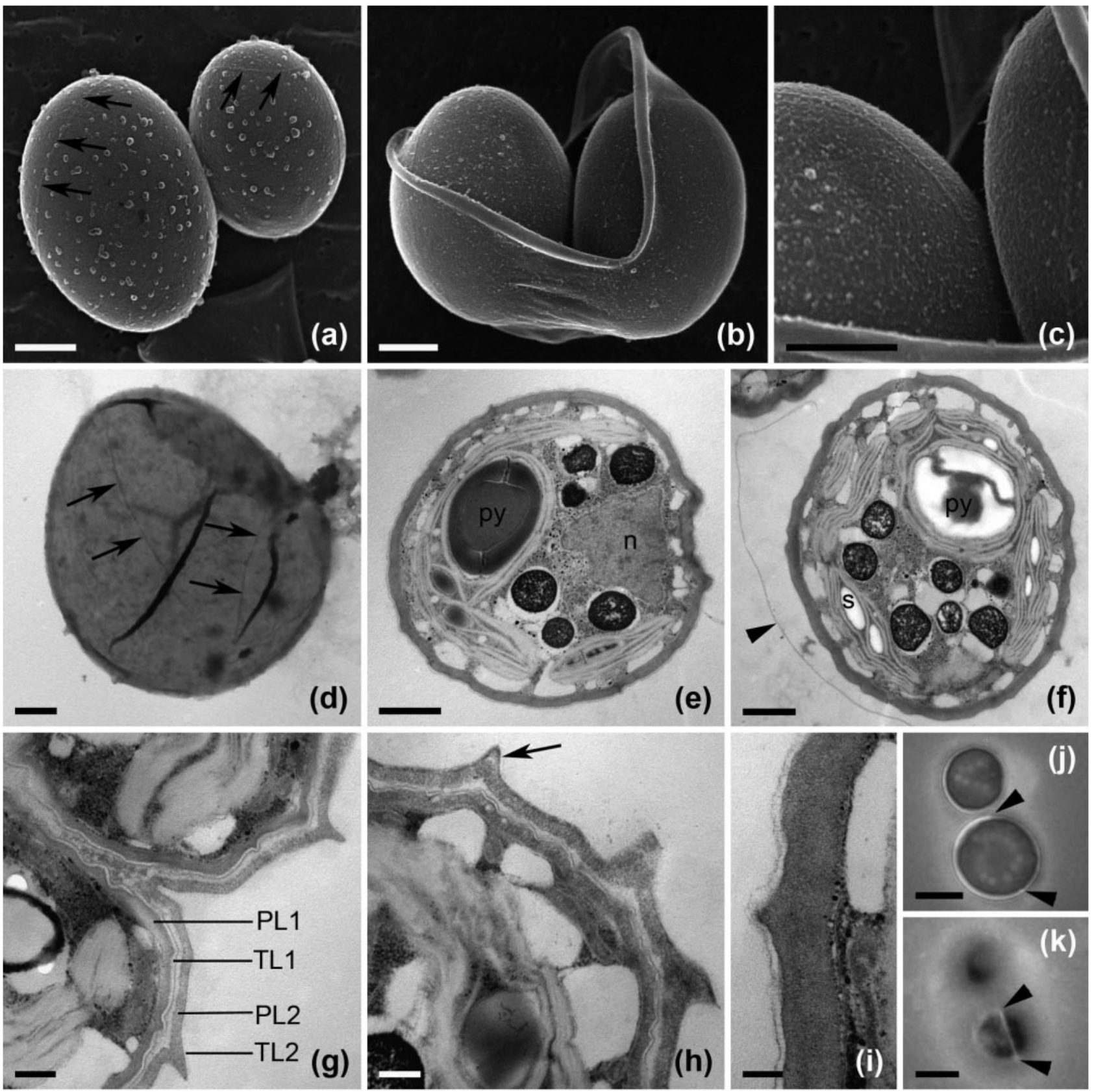

Fig. 2. Morphology and ultrastructure of $H$. singaporensis gen. et sp. nov. (a-c) H. singaporensis as observed by SEM. (a) The cell wall is ornamented by delicate, mostly meridional ribs (arrows). (b) Autospores enclosed in a parental cell wall. (c) A detailed view of the meridional rib. (d) An empty cell wall as viewed by TEM; the ribs are indicated by arrows. (e-i) TEM micrographs of cross-sections through cells of $H$. singaporensis. $(e, f)$ The chloroplast with a pyrenoid surrounded by a bipartite starch envelope. Note the vacuoles of varying size subtending the plasma membrane. The remnant of a parental cell wall is indicated by an arrowhead; py, pyrenoid; n, nucleus; s, starch grain. (g) Two newly formed autospores still enclosed in a parental cell wall; PL1, polysaccharide layer of the daughter cell; TL1, trilaminar layer of the daughter cell; PL2, polysaccharide layer of the parental cell wall; TL2, trilaminar layer of the parental cell wall. (h) A cell partly covered by a parental cell wall. The ribs are formed by both the polysaccharide and the trilaminar layer (arrow). (i) Detail of the trilaminar layer composed of an electrontransparent lamella sandwiched between two electron-dense lamellae. ( $j, k$ ) Different planes of focus on the same specimen of calcofluor white-labelled cells under fluorescence microscopy. The arrowheads point to the margin of the parental cell wall. Bars, (a-f), $1 \mu \mathrm{m}$; (g, h), $250 \mathrm{~nm}$; (i), $100 \mathrm{~nm}$; (j, k), $5 \mu \mathrm{m}$. 


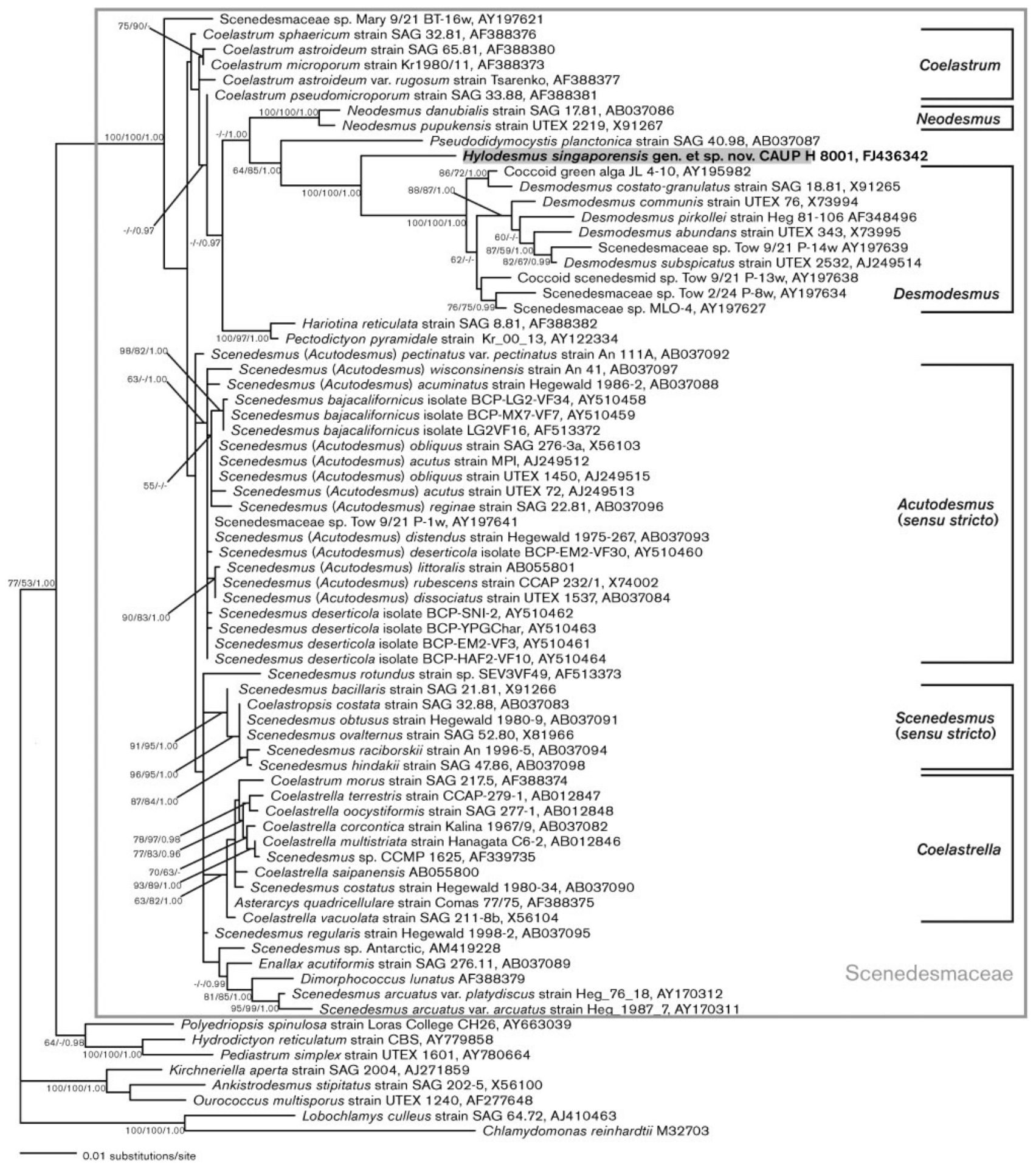

Fig. 3. Phylogenetic position of $H$. singaporensis gen. et sp. nov. CAUP H 8001 based on $18 \mathrm{~S}$ rRNA gene sequence data. The $\mathrm{ML}$ tree shown $(\mathrm{GTR}+\Gamma 4$, loglk $=-6903.361986, \alpha=0.111494)$ was constructed with RAxML-VI-HPC 2.2.3 (see Methods). $\mathrm{ML/BIONJ}$ bootstrap values/Bayesian posterior probabilities are indicated for branches when higher than 50\%/50\%/0.95. The root of the tree is placed on a branch separating Chlamydomonas reinhardtii and Lobochlamys culleus (Volvocales) and the remainder of the tree (Sphaeropleales). GenBank/EMBL/DDBJ accession numbers are provided for each sequence following the taxon name. The names of scenedesmacean taxa used in the figure often differ from the names provided in the respective GenBank entries, because we took subsequent taxonomic revisions into account (Hegewald \& Hanagata, 2000; Lewis \& Flechtner, 2004). 
aligned positions available for the phylogenetic analysis, and a highly uneven rate of evolution in different taxa. $H$. singaporensis was placed as an isolated branch within a broader clade of generally very divergent sequences attributed to the genus Desmodesmus (Fig. S2). To test whether the inclusion of the H. singaporensis ITS2 sequence within the latter genus was robust, we inferred the best ML tree while constraining the monophyly of the genus Desmodesmus to the exclusion of $H$. singaporensis. This tree, showing $H$. singaporensis in a sister position to the Desmodesmus monophylum (as in the 18S rRNA gene tree), was not found to be statistically less likely ( $P$ value of $0.214)$ than the unconstrained tree ( $P$ value of 0.786$)$, according to the Approximately Unbiased (AU) test (Shimodaira, 2002). Furthermore, we found that all available ITS2 sequences from the genus Desmodesmus have a single nucleotide deletion in the conserved helix III (Fig. S1) at a position occupied by a highly conserved ' $U$ ' residue in essentially all non-Desmodesmus scenedesmacean ITS2 sequences, including $H$. singaporensis (and ITS2 sequences from at least some other Sphaeropleales, e.g. Hydrodictyaceae).

To assess the molecular diversity of the morphotype represented by $H$. singaporensis strain CAUP H 8001, we sequenced the 18S rRNA gene-ITS1-5.8S rRNA gene-ITS2 region of the morphologically identical strain E4-g, independently isolated from the original collected sample. Compared with the CAUP H 8001, E4-g contained within its $18 \mathrm{~S}$ rRNA gene two more group I introns (four in total) and multiple substitutions or indels in the two shared introns (data not shown), but the sequence of the $18 \mathrm{~S}$ rRNA gene itself was identical. The 5.8S rRNA gene sequences of these two strains were also identical, but there were differences in the ITS1 region at five positions (data not shown), and in the ITS2 region at two positions (one in a loop in the conserved helix I and one near the $3^{\prime}$ end of the ITS2 region; Fig. S1).

\section{DISCUSSION}

The relatively simple morphology of coccoid autosporic algae is generally a poor indicator of phylogenetic relationships, but $H$. singaporensis does exhibit a suite of features indicating its phylogenetic provenance. These features include the spherical parietal chloroplast, the conspicuous simple pyrenoid surrounded by a starch envelope, and the cell wall composed of a thick, presumably polysaccharide, layer and a thin trilaminar, presumably sporopolleninic, layer; all these characters are typical for representatives of the family Scenedesmaceae (Hegewald, 1978; Komárek \& Fott, 1983; Kalina \& Punčochářová, 1987; Ettl \& Gärtner, 1995). Indeed, our analysis of $18 \mathrm{~S}$ rRNA gene sequences places $H$. singaporensis into a strongly supported monophyletic lineage of autosporic taxa that can be equated with the traditional family Scenedesmaceae (Fig. 3). The content of this clade corresponds well to analyses by Hegewald \& Hanagata
(2000) and Krienitz et al. (2003), but is expanded by a number of sequences not included by (or not available to) these authors, especially sequences attributed to Dimorphococcus lunatus, Asterarcys quadricellulare and several Coelastrum species. Hence, the diversity of the Scenedesmaceae is apparently greater than that conceived in the latest revision of this family (Hegewald \& Hanagata, 2000; see also Krienitz et al., 2003), and, although $H$. singaporensis is the latest, it will certainly not be the last arrival in this family.

However, despite the morphological hints as to the familial assignment, defining the specific phylogenetic position of $H$. singaporensis within the Scenedesmaceae would be difficult, if not impossible, without molecular data. With the notable exception of the Desmodesmus lineage, exhibiting an obvious synapomorphy in the form of a cell wall with four sporopolleninic layers ornamented with peculiar submicroscopic structures (Hegewald, 1978; An et al., 1999), other higher-level monophyletic subgroups within the Scenedesmaceae evaded recognition prior to the era of molecular phylogenetics (Hegewald \& Hanagata, 2000). For example, a strain originally identified as Chlorella minutissima (Fott \& Nováková, 1969) was later described as a new genus and species Kermatia pupukensis in the subfamily Scotiellocystoideae (Kalina \& Punčochářová, 1987), but 18S rRNA gene sequences finally showed its very close relationship to Neodesmus danubialis in the Scenedesmaceae, leading to its taxonomical re-evaluation as Neodesmus pupukensis (Hegewald \& Hanagata, 2000). Similarly, the genus Coelastrella, as currently conceived, comprises species that had been previously classified in other genera (Scenedesmus, Chlorella, Scotiellopsis, Graesiella) and that were reassigned to Coelastrella only upon a phylogenetic analysis of $18 \mathrm{~S}$ rRNA gene sequences (Hegewald \& Hanagata, 2000). Finally, neither Scenedesmus nor Acutodesmus (sensu Tsarenko) is monophyletic in the light of molecular data (Hegewald \& Wolf, 2003; see also Fig. 3). Thus, the interpretation of the morphological evolution of the Scenedesmaceae is difficult owing to a high degree of plasticity or convergence.

Nevertheless, $H$. singaporensis does display a combination of features suggesting that it probably represents an evolutionary lineage of its own, separate from species described previously. From the genus Desmodesmus, its sister group according to $18 \mathrm{~S}$ rRNA gene phylogeny, it is in all likelihood distinguished by the plesiomorphic trilaminar outer cell wall layer, and by the lack of structures comparable to 'ornaments' (granules, spines) formed by the outermost sporopolleninic layer in Desmodesmus. The genus Pseudodidymocystis, in contrast to $H$. singaporensis, lacks a polysaccharide cell wall layer, but forms unique bowl-shaped structures on the cell wall surface (Hegewald \& Deason, 1989). In addition, shed mother cell wall, which persists in the medium of $H$. singaporensis cultures (Fig. 2f), does not exhibit the typical scrolling observed in the cell walls of Pseudodidymocystis planctonica. The two known species of the genus Neodesmus are characterized 
by heteropolar cells (Hegewald \& Hanagata, 2000), and at least one of these species ( $N$. pupukensis) possesses a unique claviform pyrenoid embedded in a homogeneous starch envelope, unlike $H$. singaporensis (Kalina \& Punčochářová, 1987). Species of the genus Scenedesmus (sensu lato) generally form multicellular coenobia (Komárek \& Fott, 1983; Hegewald \& Hanagata, 2000), often have acute cell poles or polar thickenings of the cell wall (especially in the Acutodesmus group), or are surrounded by mucilage (Komárek \& Fott, 1983; Hegewald \& Hanagata, 2000) - all features not seen in H. singaporensis. Finally, Enallax acutiformis, Hariotina reticulata, Pectodictyon pyramidale and species of the genus Coelastrum are also all morphologically dissimilar to H. singaporensis (Komárek \& Fott, 1983; Hindák, 1990; Ettl \& Gärtner, 1995; Hegewald et al., 2002; Krienitz et al., 2003).

Among the known scenedesmacean taxa, $H$. singaporensis perhaps most closely resembles species currently classified into the genus Coelastrella. It also shares with most Coelastrella species the subaerial lifestyle (Ettl \& Gärtner, 1995; Hegewald \& Hanagata, 2000), so it is possible that the morphological similarities result from convergence due to similar selection pressures. However, most Coelastrella species are characterized by numerous prominent ribs on the cell surface (Kalina \& Punčochárová, 1987; Ettl \& Gärtner, 1995; Hegewald \& Hanagata, 2000), whereas $H$. singaporensis possesses only a few barely visible fine ribs (Fig. 2a, c, d). It is true that Coelastrella (=Graesiella) vacuolata also has only fine, if any (see Hegewald \& Hanagata, 2000) surface ribs, but it differs from $H$. singaporensis by generally larger cells, the absence of the peripheral vacuoles, and the production of secondary carotenoids in old cultures (Kalina \& Punčochářová, 1987). Finally, $H$. singaporensis may be similar to a species recently described from North American desert soil as Scenedesmus rotundus (Lewis \& Flechtner, 2004), although it falls outside Scenedesmus (sensu stricto) clade in the 18S rRNA gene phylogeny (Fig. 3). Unfortunately, the ultrastructure of $S$. rotundus has not been reported, so the extent of similarity, beyond features visible under light microscopy, is unknown. Regardless, $S$. rotundus is a taxon clearly distinct from $H$. singaporensis based on both the $18 \mathrm{~S}$ rRNA gene and ITS2 sequences (Fig. 3, Fig. S2).

A notable ultrastructural feature of $H$. singaporensis is the system of peripheral vacuoles (Fig. 2e, f, h). Their functional significance is unclear, but similar (homologous?) peripheral vacuoles have been observed in a TEM section of Coelastrella corcontica $(=C$. multistriata var. corcontica; Kalina \& Punčochářová, 1987), so they may not be unique to $H$. singaporensis. Likewise, structures similar to what we interpret as vacuoles containing electron-dense granular material (Fig. 2e-f) were also found in other scenedesmacean representatives, including Coelastrella (Graesiella) species and Neodesmus (=Kermatia) pupukensis, and in more distantly related taxa such as 'Chlorella' (=Mychonastes) zofingiensis (Kalina \& Punčochárová, 1987). The identity of these structures is unknown, but we speculate that they represent some type of reserve substance. Interestingly, we observed that in $H$. singaporensis a part of the parental cell wall frequently remains appressed to the surface of autospores released from the autosporangium (Fig. $2 \mathrm{~h}, \mathrm{j}, \mathrm{k}$ ). We are currently unaware of such a feature in other scenedesmacean species, but it could simply have been overlooked; therefore, further careful investigation is necessary before we can claim that this is a character idiomatic to $H$. singaporensis.

The distinctiveness of $H$. singaporensis from other scenedesmacean taxa is immediately apparent from the 18 S rRNA gene tree (Fig. 3). The overall topology of the tree is generally in accord with previous analyses (Hegewald \& Hanagata, 2000), although the clearcut division of the family into two subfamilies (Scenedesmoideae and Desmodesmoideae) is no longer supported following expanded sampling. H. singaporensis is placed into a portion of the tree comprising species with accelerated evolution of the 18S rRNA gene (note the length of the branches compared with the rest of the tree), and is firmly resolved as a lineage most closely related to the Desmodesmus clade. The common Hylodesmus + Desmodesmus node is separated from the deepest divergence within the Desmodesmus clade by a relatively long and strongly supported branch, reflecting the evolutionary gulf between $H$. singaporensis and the genus Desmodesmus. However, to date the 18S rRNA gene sequence has been determined for only a very few Desmodesmus species; therefore, with a wider sampling within this genus, it is possible that the length of this branch may become shorter. The $18 \mathrm{~S}$ rRNA gene sequences of both $H$. singaporensis and representatives of the Desmodesmus clade are highly divergent compared with sequences from most other scenedesmacean taxa, thus suggesting that the inferred Hylodesmus + Desmodesmus clade might result from the well-known long branch attraction (LBA) artefact (Felsenstein, 1978). However, the methods of phylogenetic inference employed in our study (maximum-likelihood and Bayesian methods with complex models of substitution) are relatively insensitive to this artefact (see Philippe et al., 2005). In addition, inspecting the multiple alignment of the 18S rRNA gene sequences revealed a number of substitutions synapomorphic for the Hylodesmus + Desmodesmus clade (data not shown), a finding not expected under the LBA scenario.

A much more comprehensive sampling of the diversity within Desmodesmus has been achieved with an alternative genetic marker, the ITS2 region (An et al., 1999; Hegewald et al., 2002, 2005; Tsarenko et al., 2005; Jeon \& Hegewald, 2006; Johnson et al., 2007; Vanormelingen et al., 2007). Although our ML analysis of ITS2 sequences placed the $H$. singaporensis sequence within the clade of the genus Desmodesmus, the topology should be interpreted with caution. First, all sequences of this clade are highly divergent compared with most other scenedesmacean ITS2 sequences, indicating the possibility of LBA affecting this part of the tree. Second, the number of positions of the 
ITS2 multiple alignment suitable for phylogenetic analysis is so small that stochastic error necessarily plays a role in shaping the inferred tree. Indeed, we found that an alternative topology, one with the $H$. singaporensis sequence branching off in a sister position to the monophyletic Desmodesmus clade, was not statistically less likely. Finally, the two major subclades of Desmodesmus shown in the ITS2 tree (Fig. S2) both have representatives in the $18 \mathrm{~S}$ rRNA gene tree $(D$. costato-granulatus from one subclade; and D. communis, D. pirkollei and D. subspicatus from the other subclade; see Fig. 3), where they belong, contrary to the ITS2 tree, to a strongly supported monophyletic branch excluding $H$. singaporensis. The monophyly of Desmodesmus to the exclusion of $H$. singaporensis is further supported by the apparently Desmodesmus-specific deletion of a conserved residue in helix III of the ITS2 structure (Fig. S1). Considering also the fact that $H$. singaporensis lacks morphological features characteristic of the genus Desmodesmus, these results indicate that the former is best classified in a genus separate from Desmodesmus.

Sequence variability in the $18 \mathrm{~S}$ rRNA gene or the ITS regions within morphotypes (morphospecies) of diverse unicellular eukaryotes is well-established, and has also been documented for species of the family Scenedesmaceae (van Hannen et al., 2002; Lewis \& Flechtner, 2004; Jeon \& Hegewald, 2006; Vanormelingen et al., 2007). Differences in the presence/absence of introns in the 18S rRNA gene has also been previously reported for different strains attributed to the same species of green algae (e.g. Friedl et al., 2000). It is, therefore, unsurprising to find such variability in the 18S rRNA gene and ITS sequences of the two strains examined in this study, even though they are indistinguishable at the light-microscopic level. Since the sequences of the $18 \mathrm{~S}$ rRNA gene itself are identical between strains CAUP H 8001 and E4-g, and the ITS2 region differs at only two positions without any compensatory base changes, it is probably best to consider both strains as representatives of the same species, $H$. singaporensis. It is nevertheless very interesting that we found this genetic variation in strains isolated from the same sample (a small spot of subaerial algal growth). Very little is known about the extent and structure of genetic diversity within populations of subaerial unicellular green algae, but the case of these two $H$. singaporensis strains indicates that genetically closely related, yet nevertheless different, clones might coexist in situ, without competitive exclusion of one clone by another. Further investigation is needed to evaluate the significance of these findings.

In summary, our microscopic observations and phylogenetic analyses of the 18S rRNA gene and ITS2 sequences indicate that $H$. singaporensis represents a novel phylogenetic lineage within the family Scenedesmaceae, and must be given a generic and species status separate from previously known taxa. Although the genus Hylodesmus remains monotypic at present, we expect that much greater species diversity will be revealed in future samplings, especially in those from poorly explored tropical ecosystems. Further field surveys are also necessary to ascertain the place of this organism in nature, including its geographical range, habitat distribution and ecological importance.

\section{ACKNOWLEDGEMENTS}

We thank Veronika Kučabová for her technical assistance, Dr Oldřich Benada for his excellent SEM work, Vojtěch Hladký for his help with ancient Greek, and anonymous reviewers for constructive comments on the manuscript. We would like to express our gratitude to Dr J. Leong and to Professor Benito C. Tan from the National Botanical Garden of Singapore for their field assistance and for their kind cooperation in arranging the sampling permission of the National Parks Board of the Republic of Singapore (no. NP/RP757). This work has been supported by the grant no. 206/06/0998 of the Czech Science Foundation and by the research project no. 21620828 of the Czech Ministry of Education.

\section{REFERENCES}

Abramoff, M. D., Magelhaes, P. J. \& Ram, S. J. (2004). Image processing with ImageJ. Biophoton Int 11, 36-42.

An, S. S., Friedl, T. \& Hegewald, E. (1999). Phylogenetic relationships of Scenedesmus and Scenedesmus-like coccoid green algae as inferred from IST-2 rDNA sequence comparisons. Plant Biol 1, 418-428.

Bischoff, H. W. \& Bold, H. C. (1963). Phycological studies. IV. Some soil algae from Enchanted Rock and related algal species. Univ Texas Publ 6318, 1-95.

Eliáš, M., Neustupa, J. \& Škaloud, P. (2008). Elliptochloris bilobata var. corticola var. nov. (Trebouxiophyceae, Chlorophyta), a novel subaerial coccal green alga. Biologia 63, 791-798.

Ettl, H. \& Gärtner, G. (1995). Syllabus der Boden-, Luft- und Flechtenalgen. Stuttgart: Gustav Fischer (in German).

Fawley, M. W., Fawley, K. P. \& Owen, H. A. (2005). Diversity and ecology of small coccoid green algae from Lake Itasca, Minnesota, USA, including Meyerella planktonica, gen. et sp. nov. Phycologia 44, 35-48.

Felsenstein, J. (1978). Cases in which parsimony or compatibility methods will be positively misleading. Syst Zool 27, 401-410.

Felsenstein, J. (2004). PHYLIP (Phylogeny Inference Package) version 3.6. Distributed by the author. Department of Genome Sciences, University of Washington, Seattle; 2004. http://evolution.genetics. washington.edu/phylip.html

Fott, B. \& Nováková, M. (1969). A monograph of the genus Chlorella. The fresh water species. In Studies in Phycology, pp. 10-74. Edited by B. Fott. Praha: Academia.

Friedl, T., Besendahl, A., Pfeiffer, P. \& Bhattacharya, D. (2000). The distribution of group I introns in lichen algae suggests that lichenization facilitates intron lateral transfer. Mol Phylogenet Evol 14, 342-352.

Fritz, L. \& Triemer, R. E. (1985). A rapid simple technique utilizing calcofluor white M2R for the visualization of dinoflagellate thecal plates. J Phycol 21, 662-664.

Gascuel, O. (1997). BIONJ: an improved version of the NJ algorithm based on a simple model of sequence data. Mol Biol Evol 14, 685-695.

Hanagata, N. (1998). Phylogeny of the subfamily Scotiellocystoideae (Chlorophyceae, Chlorophyta) and related taxa inferred from $18 \mathrm{~S}$ ribosomal RNA gene sequence data. J Phycol 34, 1049-1054. 
Hegewald, E. (1978). New subdivision of genus Scenedesmus. Nova Hedwigia 30, 343-376.

Hegewald, E. \& Deason, T. R. (1989). Pseudodidymocystis, a new genus of Scenedesmaceae (Chlorophyceae). Arch Hydrobiol 82, 119 127.

Hegewald, E. \& Hanagata, N. (2000). Phylogenetic studies on Scenedesmaceae (Chlorophyta). Arch Hydrobiol 136, 29-49.

Hegewald, E. \& Wolf, M. (2003). Phylogenetic relationships of Scenedesmus and Acutodesmus (Chlorophyta, Chlorophyceae) as inferred from $18 \mathrm{~S}$ rDNA and IST-2 sequence comparisons. Plant Syst Evol 241, 185-191.

Hegewald, E., Coesel, P. F. M. \& Hegewald, P. (2002). A phytoplankton collection from Bali, with the description of a new Desmodesmus species (Chlorophyta, Scenedesmaceae). Arch Hydrobiol 143, 51-78.

Hegewald, E., Schmidt, A., Braband, A. \& Tsarekno, P. (2005). Revision of the Desmodesmus (Sphaeropleales, Scenedesmaceae) species with lateral spines. 2. The multi-spined to spineless taxa. Algol Stud 116, 1-38.

Helms, G., Friedl, T., Rambold, G. \& Mayrhofer, H. (2001). Identification of photobionts from the lichen family Physciaceae using algal-specific ITS rDNA sequencing. Lichenologist 33, 73-86.

Hepperle, D., Hegewald, E. \& Krienitz, L. (2000). Phylogenetic position of the Oocystaceae (Chlorophyta). J Phycol 36, 590-595.

Hindák, F. (1990). Studies on the chlorococcal algae (Chlorophyceae). V. Biologické práce (Bratislava) 36, 1-225.

Huelsenbeck, J. P. \& Ronquist, F. (2001). MRBAYES: Bayesian inference of phylogenetic trees. Bioinformatics 17, 754-755.

Huss, V. A. \& Sogin, M. L. (1990). Phylogenetic position of some Chlorella species within the chlorococcales based upon complete small-subunit ribosomal RNA sequences. J Mol Evol 31, 432-442.

Huss, V. A. R., Frank, C., Hartmann, E. C., Hirmer, M., Kloboucek, A., Seidel, B. M., Wenzeler, P. \& Kessler, E. (1999). Biochemical taxonomy and molecular phylogeny of the genus Chlorella sensu lato (Chlorophyta). J Phycol 35, 587-598.

Jeon, S. L. \& Hegewald, E. (2006). A revision of the species Desmodesmus perforatus and D. tropicus (Scenedesmaceae, Chlorophyceae, Chlorophyta). Phycologia 45, 567-584.

Johnson, J. L., Fawley, M. W. \& Fawley, K. P. (2007). The diversity of Scenedesmus and Desmodesmus (Chlorophyceae) in Itasca State Park, Minnesota, USA. J Phycol 46, 214-229.

Kalina, T. \& Punčochářová, M. (1987). Taxonomy of the subfamily Scotiellocystoideae Fott 1976 (Chlorellaceae, Chlorophyceae). Arch Hydrobiol 73, 473-521.

Katana, A., Kwiatowski, J., Spalik, K., Zakrys, B., Szalacha, E. \& Szymanska, H. (2001). Phylogenetic position of Koliella (Chlorophyta) as inferred from nuclear and chloroplast small subunit rDNA. J Phycol 37, 443-451.

Komárek, J. \& Fott, B. (1983). Familie Scenedesmaceae. In Das Phytoplankton des Süßwassers 7 - Chlorococcales, pp. 747-945. Edited by G. Huber-Pestalozzi. Stuttgart: Schweizerbart.

Krienitz, L., Hegewald, E., Hepperle, D. \& Wolf, M. (2003). The systematics of coccoid green algae: $18 \mathrm{~S}$ rRNA gene sequence data versus morphology. Biologia (Bratisl) 58, 437-446.

Lewis, L. A. \& Flechtner, V. R. (2004). Cryptic species of Scenedesmus (Chlorophyta) from desert soil communities of western North America. J Phycol 40, 1127-1137.

Mathews, D. H., Disney, M. D., Childs, J. L., Schroeder, S. J., Zuker, M. \& Turner, D. H. (2004). Incorporating chemical modification constraints into a dynamic programming algorithm for prediction of RNA secondary structure. Proc Natl Acad Sci U S A 101, 7287-7292.
Mattox, K. R. \& Steward, K. D. (1984). Classification of the green algae: a concept based on comparative cytology. In Systematics of the Green Algae, pp. 265-292. Edited by D. E. G. Irvine \& D. M. John. London: Academic Press.

Neustupa, J., Eliáš, M. \& Šejnohová, L. (2007). A taxonomic study of two Stichococcus species (Trebouxiophyceae, Chlorophyta) with a starch-enveloped pyrenoid. Nova Hedwigia 84, 51-63.

Neustupa, J., Němcová, Y., Eliáš, M. \& Škaloud, P. (2009). Kalinella bambusicola gen. et sp. nov. (Trebouxiophyceae, Chlorophyta), a novel coccoid Chlorella-like subaerial alga from Southeast Asia. Phycol Res 57, 159-169.

Oltmanns, F. (1904). Morphologie und Biologie der Algen. Band I. Jena: G. Fischer.

Philippe, H., Zhou, Y., Brinkmann, H., Rodrigue, N. \& Delsuc, F. (2005). Heterotachy and long-branch attraction in phylogenetics. BMC Evol Biol 5, 50.

Pouličková, A., Žižka, Z., Hašler, P. \& Benada, O. (2007). Zygnematalean zygospores: morphological features and use in species identification. Folia Microbiol (Praha) 52, 135-145.

Rindi, F., López-Bautista, J. M., Sherwood, A. R. \& Guiry, M. D. (2006). Morphology and phylogenetic position of Spongiochrysis hawaiiensis gen. et sp. nov., the first known terrestrial member of the order Cladophorales (Ulvophyceae, Chlorophyta). Int J Syst Evol Microbiol 56, 913-922.

Senousy, H. H., Beakes, G. W. \& Hack, E. (2004). Phylogenetic placement of Botryococcus braunii (Trebouxiophyceae) and Botryococcus sudeticus isolate UTEX 2629 (Chlorophyceae). J Phycol 40, 412-423.

Shimodaira, H. (2002). An approximately unbiased test of phylogenetic tree selection. Syst Biol 51, 492-508.

Shimodaira, H. \& Hasegawa, M. (2001). CONSEL: for assessing the confidence of phylogenetic tree selection. Bioinformatics 17, 12461247.

Stamatakis, A. (2006). RAxML-VI-HPC: maximum likelihood-based phylogenetic analyses with thousands of taxa and mixed models. Bioinformatics 22, 2688-2690.

Stamatakis, A., Hoover, P. \& Rougemont, J. (2008). A rapid bootstrap algorithm for the RAxML web servers. Syst Biol 57, 758771.

Thompson, J. D., Gibson, T. J., Plewniak, F., Jeanmougin, F. \& Higgins, D. G. (1997). The CLUSTAL_X windows interface: flexible strategies for multiple sequence alignment aided by quality analysis tools. Nucleic Acids Res 25, 4876-4882.

Tsarenko, P. M. \& Petlevanny, O. A. (2001). Doplolnenie k 'Raznoobraziju vodoroslej Ukrainy'. Algologia Suppl. (unnumbered), 1-130 (in Russian).

Tsarenko, P. M., Hegewald, E. \& Braband, A. (2005). Scenedesmuslike algae of Ukraine. 1. Diversity of taxa from water bodies in Volyn Polissia. Algol Stud 118, 1-45.

van Hannen, E. J., Fink, P. \& Lürling, M. (2002). A revised secondary structure model for the internal transcribed spacer 2 of the green algae Scenedesmus and Desmodesmus and its implication for the phylogeny of these algae. Eur J Phycol 37, 203208.

Vanormelingen, P., Hegewald, E., Braband, A., Kitschke, M., Friedl, T., Sabbe, K. \& Vyverman, W. (2007). The systematics of small spineless Desmodesmus species, D. costato-granulatus (Sphaeropleales, Chlorophyceae), based on ITS2 rDNA sequence analyses and cell wall morphology. J Phycol 43, 378-396.

White, T. J., Bruns, T., Lee, S. \& Taylor, J. W. (1990). Amplification and direct sequencing of fungal ribosomal RNA genes for phyloge- 
netics. In PCR Protocols: A Guide to Methods and Applications, pp. 315-322. Edited by M. A. Innis, D. H. Gelfand, J. J. Sninsky \& T. J. White. New York: Academic Press.

Wolf, M., Hegewald, E., Hepperle, D. \& Krienitz, L. (2003a). Phylogenetic position of the Golenkiniaceae (Chlorophyta) as inferred from $18 \mathrm{~S}$ rDNA sequence data. Biologia (Bratisl) 58, 433436.

Wolf, M., Krienitz, L. \& Hepperle, D. (2003b). On the phylogeny of Radiococcus and Schizochlamydella (Radiococcaceae, Chlorophyta). Biologia (Bratisl) 58, 759-765.
Wuyts, J., De Rijk, P., Van de Peer, Y., Pison, G., Rousseeuw, P. \& De Wachter, R. (2000). Comparative analysis of more than 3000 sequences reveals the existence of two pseudoknots in area V4 of eukaryotic small subunit ribosomal RNA. Nucleic Acids Res 28, 46984708.

Zhang, J. M., Huss, V. A. R., Sun, X. P., Chang, K. J. \& Pang, D. B. (2008). Morphology and phylogenetic position of a trebouxiophycean green alga (Chlorophyta) growing on the rubber tree, Hevea brasiliensis, with the description of a new genus and species. Eur $J$ Phycol 43, 185-193. 